\title{
高分子の強度はどこまで 上げられるか
}

高柳 素夫

Motowo Takayanagi, 九州大学工学部応用化学科

\section{1. はじめに}

これまでプラスチック，ゴム, 繊維などの高分子材 料の強度的性質の常識的なデータは容易にハンドブッ クに見いだされ，本来そのようなるのだと受け入れる 向さがあった，衣料用合成繊維では $10 \mathrm{~g} / \mathrm{d}$ の強度が あれば十分で，より配向度を高めてピリングなどの他 の性質を犠牲にすることは不利だといわれてきた。こ こに新たに「高分子の強度はどこまで上げられるか」 との質問が発せられたのは，激変するわが国の社会， 経済構造の変化に応ずる技術革新の要請があってのこ とと考光る。

私はすでに本誌1,22で高分子の高次構造を検討する と, 応力を支持する主体は, 数\%にすぎない共有結合 からなる高分子鎖, すなわち tie molecule であり, 他の大部分の高分子鎖は屈曲性のものである限り, エ ントロピー的に有利なランダムコイル状，ないしは折 りたたみ結晶になり，力を支える上にはきわめて能率 の悪い状態であることを繰り返し述べてきた，上記の くるまり，折りたたまれた分子鎖は後述する理論強度 を参照すると，いわぼ余分の脂肪，ぜい肉であり，こ れを削り沶とすと金属板を代替するに十分な強度, 弾 性率, 寸法安定性も期待され, 事実このことは数值的 には可能でする、これる自螅車ボディーに用いれば， 軽量でガソリン消費を節約できるし，今や高価な石油 資源そのものともいらべきプラスチックからぜい肉を 特として今の $1 / 10$ の薄板化が害現できれば，省資 源, 省エネルギーへの寄与は大さい，同様なことは高 強度, 高弾性率の要望が高まってきたラジアルタイヤ にもいえるが, ここでは低発熱, 高ゴム弾性の機能も 別に両立するよう設計が必要である.

グラファイト繊維強化複合材料がロッット用液体燃

How to Raise the Polymer Strength to Its Limit
料の耐压容器としてアポロ計画に用いられて以来, 今 や人工衛星は通信外飞子気象, 海流, 地質, 資源探查な どを含む数元切れぬ社会的然与をしようとしている。 これらは極限環境に特沙る強度探究の成果である.

金属を代替するエンジニアリングプラスチックにつ いては，すでに使用時の信頼度の評価を必要とする时 代に入った，耐疲労性は静的破壊強度よりもはるかに 低い応力水準で問題となる強度的性質で, 破壊力学の 好個の研究対象であり,クラック成長の制御の工夫が 必要である.

これらの要望に対する技術的アせスメントを行なら には，力学物性の基礎に立ち返り，理椧の示吉限界を 明らかにし，本来実現しえないことはとれを受入れ， 可能性のある範囲で新規の発想をもって挑戦を試みる 必要がある。

\section{2. 分子鎖強度の理論一一変ええざるもの}

\section{2-1. 原子間共有結合の理想強度}

高分子鎖は通常共有結合よりなる、教科書にあるよ らに, 原子間距離 $l$ を横座標にとるとェネルギ一 $(U)$ 曲線は斥力範囲で急な負勾配， $l=l_{0}$ で極小の平衡位 置をとり，lの增加ととすにゆるやかに正勾配で上昇 していくが勾配に変曲点 $l_{b}$ がある、結合をゆが皇せ る力 $f=\mathrm{d} U / \mathrm{d} l$ は $l=l_{b}$ で極大值をとり, それより 下降する. 結合のバネ定数 $K=\mathrm{d} f / \mathrm{d} l$ は $l=l_{b}$ で 0 となり，破断がここで起こる. C-C 結合について Morse 関数を仮定し, $U_{0}=332 \mathrm{~kJ} \mathrm{~mol}^{-1}(83 \mathrm{kcal}$ $\left.\mathrm{mol}^{-1}\right), \mathrm{C}-\mathrm{C}$ 結合の振動数, 換算質量などから Morse 関数のパラメータ值を求め, $l_{0}=0.154 \mathrm{~nm}$ $(1.54 \mathrm{~A})$ とすると, 破断応力 $\sigma_{b}$ は $32.3 \mathrm{GN} \mathrm{m}^{-2}$ $\left(3,300 \mathrm{~kg} \mathrm{~mm}^{-2}\right)$ ，破断伸び $\varepsilon_{b}=\left(l_{b}-l_{0}\right) / l_{0}$ は $21 \%$ となる. 計算方法により $\sigma_{b}=19.6 \mathrm{GN} \mathrm{m}^{-2}, \varepsilon_{b}=22 \%$ の結果もあり, 量子力学的計算では $\sigma_{b}=18.6 \mathrm{GN}$ $\mathrm{m}^{-2}, \varepsilon_{b}=33 \%$ などの文献值がポリェチレンについて 
見いだされる、的が予想外に大きいことが注目され る.

こうした形式で計算した理想強度, ならびとその概 略值を約 13 種の高分子飞ついて前回2) 表示したが, そこには isotactーポリ(4-メチル 1-ペンテン)の、の $7.2 \mathrm{GN} \mathrm{m}^{-2}$ の最低值季で岁る. これは分子鎖の断面 積が大きくなると試料単位断面積を横切る共有結合数 が少なくなる結果で努る.これらの数值はまだ笑験的 に検証された例はない。

\section{2-2. 応力下の熱活性化された共有結合の破断}

ここでは分子論的考察をすすめているのであるが， その出発点となった重要な実験事実がある。そ机は Zhurkov 3) が種々の金属と高分子とについて行なった クリープ破壞の寿命に関するすのである. 第 1 図のよ らに（A）ポリ(メタクリル酸メチル)，(B）ビスコ 一ス，(C) ナイロン 6 に一定の伸張荷重を加光, 破 壤時間 $t_{b}$ を図に示した各温度で伸び応力 $\sigma$ の関数と して测定すると, $\log t_{b}(\mathrm{~s})$ 対 $\sigma\left(\mathrm{Nm}^{-2}\right)$ の関係は負 勾配の直線関係を示し，これを補外 すると, 各試料炎れぞれ $t_{b}=10^{-13} \mathrm{~s}$ の一点潗束する。この笑験式は (1) 式で表わされる.

$$
t_{b}=\frac{1}{\omega} \exp \left\{\left(U_{0}-\gamma \sigma\right) / R T\right\}
$$

ここで $U_{0}$ は結合の平衡状態からの 解離竔ルギー，以は分子振動の周 波数 $10^{13} \mathrm{~s}^{-1}$ と見なす。 $\gamma$ はの 有効性を示す係数で，大きい值传ど 結合は不安定となる。この関係を分 子論的に表現すると，一様な共有結 合の連鎖をモデルとして，0K から試験温度（室温な ぞ）になると, 赤外吸収に特性的な C-C 結合の伸縮 振動に特性的な高次の振動（ごく低温から開始してい る）に加えて，それらが連成した波長の次第に大きな 低次の振動まで励起され重畳してくる. 然応力下では この振動エネルギーは $4 \sim 8 \mathrm{~kJ} \mathrm{~mol}^{-1}$ で影るから， $U_{0}$ 值に比較して十分に小さく解離の確率は無視できる. しかるに, 応力 $\sigma$ により, 断面積 $A$ の 1 本の分子軸 に $\psi$ なる力が加わり， $l_{0}$ の結合が $l$ まで伸びたとす ると $\Delta W=A \psi\left(l-l_{0}\right)$ なる外力による仕事がこの結合 飞加わり, 解離, 寸なわち破断の活性化エネルギーは $\left(U_{0}-\Delta W\right)$ と浅くなる. この結合が振動数 $10^{13} \mathrm{~Hz}$ で振動しているとこの結合の切断する確率 $K$ は (2) 式となる.

$$
K=\omega \exp \left\{-\left(U_{0}-\Delta W\right) / R T\right\}
$$

$K^{-1}$ 老破断時間 $t_{b}$ K等しいとすれば，(1) 式の实験
式にそのまま書き換光られる，ただ $\gamma_{\sigma}$ を $\Delta W$ に等 置するためには，分子軸が一様洒配向し均質であると いうモデルKなるが，現実の複雑な高次構造をるつ高: 分子材料については到底許容できない仅定である.分 子の凝集構造が複雑であれば，加わる力による応力分

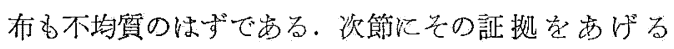
が, ここでは破壇に決定的な特定の分子鎖の切断が上 記の機構で起こるとして, 係数ては応力 $\sigma$ をその部 分飞集中させる有效性を示す尺度と解釉して和く。ナ イロン 6 綫維では $\gamma$ の理想值 $0.1 \sim 0.17$ 飞対し測定. 值は 1.21 ，ポリプロピレン繊維では 0.42 K対し 2.68 などの数値があげられているう2.

第 2 図汇は $\mathrm{Kausch}^{4)}$ がナ゙イロン 6 の分子軸に $\phi=$ $20 \mathrm{GNm}^{-2}$ の応力它加党たとき， $U_{0}=188 \mathrm{~kJ} \mathrm{~mol}^{-1 \mathrm{k}}$ (45 kcal mol-1) が $U=67.0 \mathrm{~kJ} \mathrm{~mol}^{-1}\left(16 \mathrm{kcal} \mathrm{mol}^{-1}\right)$. に減少し，室温の破壞確率が $1 / e^{25}$ となり，括そらく 分のオーダーで切断するであるらといら計算例を示し て物く。

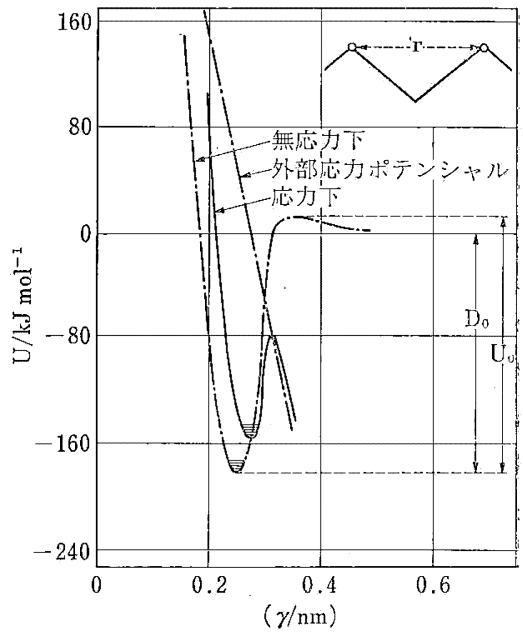

第 2 図 C-C-C 鎖のエネルギー出線の応力 $(\phi=$ $\left.20 \mathrm{GN} \mathrm{m}^{-2}\right)$ による変化 $\left(\right.$ Kausch $\left.^{4)}\right)$

高分子 27 巻 2 月号 (1978年) 
以上述べてきたことは強度を考虑する上で逃れるこ とのできないものである、ただ（1）式のケには高次構 造に上る応力の不均質性が入っです, ただ一つの変 えうるパラメータで㟧る。

\section{3. 構造の影響——变えうるもの}

\section{3-1. 一次構造}

前章では分子軸の完全配向を想定した。もし伸び応 力方向に対して結晶分子軸方向が傾斜していれば, 分 子軸相互のすべりによる結晶のセン断変形が起こり， 究極的には一部分子鎖の分子軸の伸び切った間隙に， もはやセン断応力成分の無視できる状態になった折り たた2鎖の結晶が残存することになる．これが高配向 㵶維構造で西る。この上うになるのはポリェテレン結 晶のセン断強度が $0.2 \mathrm{GNm}^{-2}$ 2 で, 共有結合強度の $33 \mathrm{GN} \mathrm{m}^{-2}$ と比較になら炡ど小さいからで劣る。 らした高次構造についての考察からすれば, 本来折り たたむことがエネルギ一的に不可能な一次棈造をむつ 分子鎖を束状に凝集できるならば問題が解決し, 強度 と弾性率とは飛躍的に增加するはずである. Kevlar 飞象徽される全芳香族系剛直高分子はまさに艺の例で あり，紡系原液中で液晶を形成することが束状凝集を 成功させた，たた鎖長が短い時に分子間すべりが起こ り，分子鎖末端部が潜在欠陥として働き，強度に限界 を与兄ている、いずれ炕せこの小文の主題である設 問に対するもっともすばらしい解答であることに間違 いない.

\section{3-2. 高次構造における応力不均質の実証}

屈曲性高分子飞話をもどし，実際に応力に不均質性 のあることを説明する適切な策例を二つ示そう。

DeVries ら6) はポリプロピレン配向フィルムの C$\mathrm{C}$ 伸縮振動による $975 \mathrm{~cm}^{-1}$ の赤外特性バンドが, 第

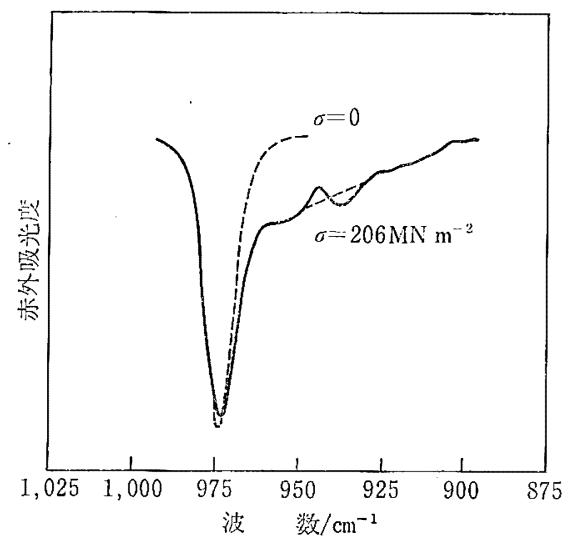

第 3 図 応力による配向ポリプロピレンの 974.5 $\mathrm{cm}^{-1}$ 赤外吸収スペクトルの変化(DeVries 5)
3 図に示すようにマクロ応力により低波数側に尾を引 くのは，各結合上のミクロ応力に広い分布があるため. であるとしている，そこで C-C 結合を「原子変換器」 と見たてて，応力と波数位置との検定曲線を作製すれ ば, 各結合上のミク口応力の分布状態が評洒される. その結果が第 4 図である. この分布曲線を見ると，応 力をさほど受けていない結合が大部分であり，少数の 結合が過度の応力を担っていることがわかる．このよ らな応力集中性, 配向物のモルホロジー, その他の知見 から、クリスタリット間の非晶領域にあって, クリス タリットを結ぶ tie molecule であると推諭される。

さてこの場合の tie molecule に長さの分布が势る ことは，ESR 法により適確に証明できる。このような 場合には，伸びひずみとともに主鎖切断による一次ラ ジカル濃度が連続的炕増加していくはずである。この 目的で長村ら ${ }^{8)}$ はポリ（ $p$ ヒドロキシェトキシ安息香 酸）繊維を選んだ.この緎維は室温で真空ないし窒素 気流中で延伸すると，主鎖切断火上る安定なフェノキ シラジカルルよる非対称三重線 ESR スペクトルを与

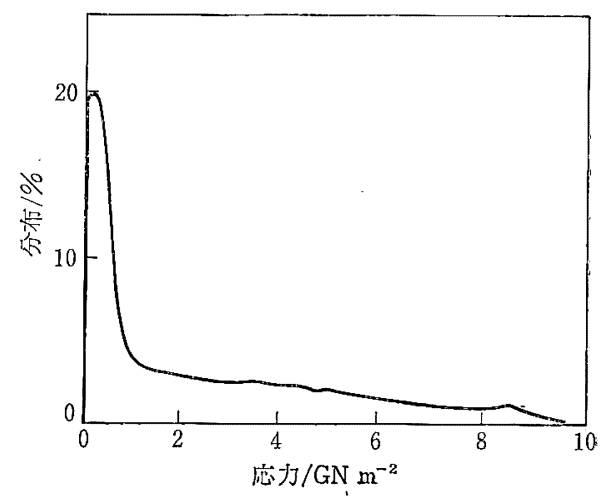

第 4 図 第 3 図から評価した応力の不均筫分布 曲線 (DeVries $5^{6)}$ )

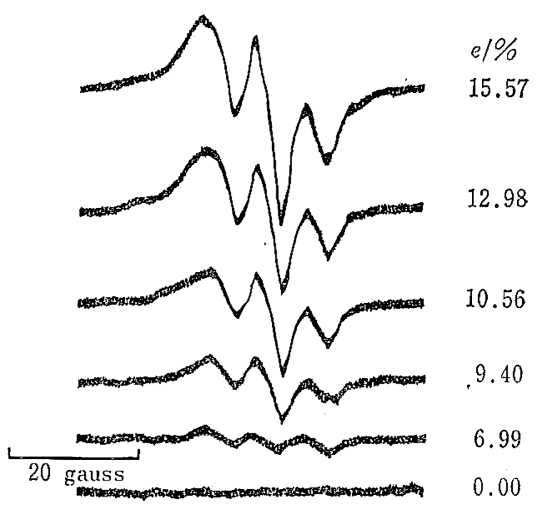

第 5 図 ポリ( $p$ ーヒドロキシエトキシ安息香酸) 絨維の伸張による ESRスペクトルの变化 $e$ は伸度 (長村, 高柳》),8) 
え，計算との一致炕る 完全な同定もできている7》. 第 5 図にそのスペクトルの伸びによる变化を示す8). ラジカル濃度対ひずみの関係怔正規分布の積分形で表 わされ，高次構造パラメータを用いると分子鎖長の分 布まで得られる、緊張を受けた分子鎖から順次, 伸 張，破断を起こしていくという仮定により，上記の分 布を用いると $20 \%$ ひずみまでの応力ーひずみ曲線を 再構成できる8).

\section{3-3. 均質配向への努力と限界}

上述の結果をみれば現害の材料では，それを構成す る分子鎖の一部しか大きい応力を支兄て频らず，大部 分の分子鎖は折りたた栾れ，西るいはくるまって有効 でない，そこでこのような効率的でない分子鎖をすべ て一様に伸張して配向させることが強度向上の指針々 して策定される，この方向の努力を二，三述べょう．

まず一次構造では分子鎖末端が欠陥となるから，鎖 長 $P$ を長くする．無限重合度の繊維の強度を $\sigma_{\infty}$ と すると (3) 式の関係が導かれ, 実験結果も形式的に支 持することが知られている.

$$
\sigma_{b}=\sigma_{\infty}\left(1-P^{\prime} / P\right)
$$

ここで $P^{\prime}$ は, 完全一様配向の理想モデルでは, 破断 面から分子鎖末端まで $P^{\prime}$ の距離にあれば，この分子 鎖は引引き抜かれるといら限界の長さ。これより長けれ ば分子鎖が破断する臨界長で，結晶内部の分子間ポテ ンシャルにより各主鎖原子が保持される力を $f_{M}$ とす れば (Lennard-Jones ポテンシャルから計算できる), 分子鎖切断の力を $f_{B}$ として, $P^{\prime}=f_{B} / f_{M}$ 之概算され る.この計算る応力と温度の効果を考虑すると簡単で ないが, ナイロン 66 では $1.67 \mathrm{~nm}$, ポリェチレンで は $8.05 \mathrm{~nm}$ などの計算結果がある゙．前者は水素結 合の影響が大きく $P^{\prime}$ は小さい. (3) 式の第 2 項は $2 /$ $P$ の末端基濃度が破断面をはさむ $2 P^{\prime}$ の距灕に現方 れる確率とみてもよい。

次に高次構造については, 折りたたまれ,くるまっ た分子鎖を引き伸恬すのにもっとも有效な温度条件が ある. 通常, 分子鎖を引き拔く応力は無定形高分子で は $T_{g}$, 結晶性高分子では $T_{m}$ で無視され, 低温にな る注ど抵抗力は大きくなり, ある温度で臨界応力 $\sigma_{c}$ で分子鎖が破断して破壊するゼイ性破壞域に入 る2. 延伸温度が低すぎると，一部応力集中した分子 鎖の破壞飞伴なら局所的クラックが生じ, 白化が見ら れる．このクラックは後述するように強度に致命的で ある、配向状態もこのため不均質となり不完全とな る. 他方, 延伸温度が高すぎると分子鎖の引き抜きが 抵抗応力の低下に伴ない容易になるが，引き拔かれた 分子鎖は外力に上る拘束力が少ないために結晶は発達 しても配向は延伸応力の不足のために低下する，延伸
温度を横軸にとると, 配向を表わす複屈折度, 伸び弾 性率, 強度は, ポリェチレン, ポリプロピレン, ポリ オキンメチレンなどの結晶した高分子を通じ，結晶領 域で粘弾性緩和を示す温度域で極大值を示す99. 結晶 綬和では，結晶格子内の分子鎖が大きい振幅の非調和 熱振動を起こしているから，その分子鎖は円滑に引き 拔かれるとともに，な結晶ポテンシャルによる分子 鎖の変位に対する抑制力が適当に働いていることが高 度延伸の温度として最適条件を与えたことになる。

この温度条件は, 最近超延伸と呼ばれる一群の高弾 性率配向物についても当たっている. 静水王条件が加 わる時汇若干高めの温度が採用されるが, 緩和温度 の圧力による高温側への移行を考慮すれば当然であ る.ポリエチレンの例では木方ら ${ }^{10) か ゙ ~ z o n e-d r a w i n g ~}$ 法淿より $110^{\circ} \mathrm{C}$ で 36 倍延伸乙, 伸び弾性率 $73 \mathrm{GN}$ $\mathrm{m}^{-2}$ を得, Ward $ら^{11)}$ は未延伸物の分子量, モル木 ロジーを工夫して, $75^{\circ} \mathrm{C} て ゙ 30$ 倍, 弾性率 $70 \mathrm{GN}$

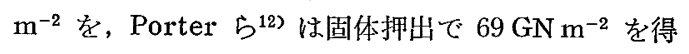
ている. 通常, X線による結晶弾性率の約 $1 / 3$ で, 理論弾性率值は後者よりかなり高い值を示す, 第 6 図 のように横軸に延伸倍率をとり綎軸に伸び弾性率をプ ロットすると, ポリプロピレン, ポリオキシメチレン を含め, いずれも30 倍ないしそれ以下で飽和值濑 近する傾向を示寸，これ以上の延伸は，試料の破壤が 起こるために果たせない。

このよらな延伸の限界が現われる事実汶する著者 の解釈は，延伸倍率により弾性率が向上するととも に,わずかのひずみによっても試料中に蓄積されるひ ずみエネルギー $\varepsilon_{s}$ は大きくなり，分子鎖末端などい

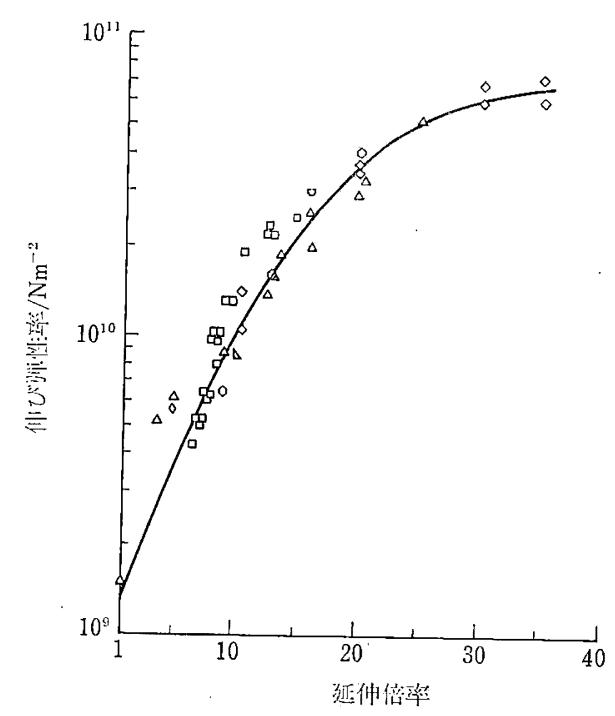

第 6 図高密度ポリエチンンの弾性率対延伸倍率 (文献データの集積) ( Bigg $^{13)}$ ) 
かに注意しても除さ点ない潜在欠陥がいったんクラッ クになると，クラック成長の推進力となるエネルギー 解放率 $G=-\partial \varepsilon_{s} / \partial c$ ( $2 c$ はクラックの長さ) の值がき わめて大きくなり，ゼイ性破壊を誘発しやすくなると 考える、すなわら，高弾性率にすることと，クラック 成長によるゼイ性破䘫の容易さとが平行して生起する 宿命にある、したがって, 現在以上に弾性率当向上し ようとすれば，クラックの原因となる欠陷を抜本的に 断ら切ることが先決問題である. 純粋な試料を真空中 で注意深く延伸することも一方法であるう。あるは クラック先端に括いて, 応力集中によるエネルギーを 減衰させるように特定の結晶面がすべりを起こすよう に配向を工夫することも一方法であるう。いずれにせ よ飽和しようとする进線の勾配を上向けることは一通 りの苦労では済まないであるう。

\section{4. 破壊力学と強化原理の活用}

\section{4-1. 高分子の破壊力学}

前章で一様な高延伸は単純な幾何学モデルでは理想 強度を実現しそら火思觉ながら，そこに第6 図に例示 したような突破し難い壁があり，これはクラック成長 の促進効果によると推論した. この点を若干補足し て沶く必要がある。破壇力学は Griffith 火始まる (1920). 試験片中に潜在欠陷があり，一様な弾珄ひず みを与党た場合に応力集中源となり，クラックの成長 が以下の臨界条件を㵞足した洔に起こる. 長さ $2 c$ の クラックに平均応力 $\sigma$ 加加えられたとき, 系の全ェネ ルギー $\varepsilon$ はひずみエネルギー $\varepsilon_{s}$ とクラック部の表面 エネルギー $\varepsilon_{\gamma}$ との和から成る. この時, クラックの 進行は新表面をつくるから $\varepsilon_{\tau}$ は $c$ ，とともに增加し， ひずみエネルギーの一部はクラックの発生により解除 されるから $\varepsilon_{s}$ は $c$ とをも減少する，そこで（4) 式の平衡条件を渾足した時がクラック成長の臨界条件 となり，この場合の $\sigma$ が破猿応力 $\sigma_{f}$ となる.これ以 後は解放されるひずみエネルギーの減少が駆動力とな ってクラックが進行するのみである. すなわら平衡条 件证

$$
\frac{\partial \varepsilon_{s}}{\partial c}+\frac{\partial \varepsilon_{\gamma}}{\partial c}=0
$$

(4) 式の解は， $E$ を伸び弾性率， $\gamma$ を表面ェネルギー として (5)式で表わされる.

$$
\sigma_{f}=(2 E r / \pi c)^{1 / 2}
$$

(5) 式をポリスチレン, ポリカルボナートなどに適用 すると, $\boldsymbol{~}$ の值は表面エネルギーの理椧值より異常に 大きくなる. Kambour ら ${ }^{14)}$ は $\gamma$ の内容を, クレー ズの構造と変形挙動の測定から，海綿状のクレーズの 形成と，その粘弾的変形の仕事が大きい割合を占める
と説明している，Rivlin-Thomas ${ }^{15)}$ はゴムの引き裂 きェネルギー $T$ を(4) 式の $\varepsilon_{r}$ の代わりに用いたが, 最近の Andrews 理諭 ${ }^{16)}$ ではもら一度 Griffith 理論 の基本的な考光にさかの湾り，高分子特有の応力ーひ ずみ曲線の負荷－除負荷サイクルに見られるとステレ シスループに相当するェネルギー損失は，クラック成 長に寄与しえないこと, 回復可能なエネルギーこそ $\varepsilon_{s}$ であることを指摘し，この関係の表式化と実䋡的 検証をゴム，低密度ポリエチレン，可塑化塩ビについ て行なっているが，その詳細は深堀 ${ }^{17}$ により紹介され た.クラック成長による除荷重の影響がこれまでの理 論では定量的に考慮されていなかったことを注目した い，伸び切った分子鎖のような完全弾性体ではロスが ないから，分子鎖切断に最低限必要な入力エネルギー が与党られると即座に破懐を起こす，これが前章に述 ベた延伸限界の現象の破壤力学による説明である。一 方, 可塑変形を起こし，ひずみェネルギーの吸収の大 きい材料では，上と同じクラックがあっても成長せず に系全体が変形するに止悉る可能性の方が高い。

\section{4-2. 高分子強度向上の活路}

均質配向への努力はゼイ性破壊による弾性率, 強度 の頭打ちを現実にはもたらし，破噮力学からすれば欠 陥敏感性を高め, クラック成長の推力を増すことをこ れまで述べてきた.これに対して，クラック鈍感にし ようとすれば材料のヒステレシスロスを大きくするこ とで, 小変形の線形粘弾珄の言葉で言光ば内部摩擦に よる損失弾性率を大さくすることになる。それには分 子鎖の凝集構造を乱し, 変形の際の分子鎖セグメント の変位を大きくして分子環境との間に摩擦によるエネ ルギー損失を生ぜしめる必要がある，このことは，本 来，分子鎖の高眍向を達成しょうとすることと满造上 からも矛盾する.

ここに拈いて両因子を両立させる道はただ一つしか 考えられない，それは複合材料の強化原理によること である.この小論で意をつくすわけにはいかぬから， そのエッセンスにのみられておこう。本の棒はそれ に内在する欠陥のらちもっとも弱いものからクラック を成長させて破断する。しかし，同じ材質のフィラメ ントをより合わせて棒と同じ直径のロープとする，同 様に弱い欠陥があってもとれを含さフィラメントは破 壤するが，クラックはフィラメント界面でフィラメン 卜軸に沿って拡散し直接隣接フィラメントに伝播せず に済を．伸びの力はフィラメントどうしの界面に法線 応力を働かせ, 摩擦係数によってフィラメント間の変 位は止められ, マク口応力は一様にフィラメントに分 布する.このような效果は伸びの大きいフィラメント で特に有效である.もしガラス繊維であれば接触部で 
傷がつき欠陥を多発するから，不飽和 ポリエステルなどの延性的なマトリッ クス樹脂でフィラメント間の応力伝達 の役を果たさせればよいし，このマト リックス自体は延性的であるから破壊 力学からクラックは発生しない.こう してクラックの成長は巧妙に阻止され る. 繊維は十分にその強度を発揮す る.

そこでこのような複合材料の強化原 理を分子レベルに降るして高分子系に ついて考光る. 香ずロープであるが， 驚く淰ど精繳なことには，自然はこの 原理を分子レベルにまで活用してい る. 生体の強度構造材料であるコラー ゲンは三本鎖重らせんのトロポコラーゲン(TC)を構 成要素としている。第7 図は TC の構造の説明図で

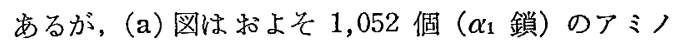
酸が特定の配列で $\alpha$ ーヘックスと呼ばれるコンホメ ーションをとっている.これを minor helix とよぶ. $\alpha$ ーヘリックスはアミノ酸 3 残基でピッチを形成する. 次に (b) 四では 3 アミノ酸残基を単位として,さらに 10/1ないし7/1らせんを形成している。これをmajor helix とよぶ. (c) 因は 3 本の major helix が中心軸 を共通集合し重らせん（coiled coil）を形成してい る.これが TC である。この構造は Pro-Pro-Gly を単位とする合成尔リペプチド (Pro-Pro-Gly) 10 な るコラーゲソモデルについて分子間相互作用を考虑し てェネルギー的に計算した結果からる，孤立鎖として 存在するよりエネルギー的に安定であることが示され た ${ }^{18)}$.この構造は前述したロープの機能のすべてを満 足した最小の形態である.

さら驚くことは，TC がさらに5本よられてミク ロフィブリルを形成している. TC を円筒にみたてる 之, 7/1 らせんをとる場合に限りその円筒表面の 3 箇 所に大型の眯水性基をもつアミノ酸残基の分布が片寄 ってくる. その 2 笝所で二つの隣る TC との間につよ い相互作用があるとすると，ちょうど5 個の TCを一 つの円筒面上にまきつけたミクロフィブリルの構造が エネルギー的炕安定であることが説明できる ${ }^{199}$ 。これ が正方格子に並んでサブフィブリルとなり，これが寄 って $100 \sim 500 \mathrm{~nm}$ 径のフィブリルを形成する。 これ らフィブリルは平行に集委り絨維層を形成し，各層が 直交して重なった層状構造をとることが表皮下の組織 の電子顕微鏡写真に見られる.フィブリル間物質は水 和したマトリックスで, この系はまさに繊維複合材料 のマク口構成とのものである. クラックの成長により
簡単に破壊せぬよう, 単独の分子鎖 $(\mathrm{TC})$ の強度まで 徹底した配虑がなされていることは, 自然の摂理とは いえ巧妙をきわめたものである。

私どす㤝このような自然穴のものを再現することは 不可能で政ることを知っている. しかし何らかの複合 化を分子レベルで試みることは不可能ではない，すで に分子鎖のコンホメーションを評仙すること，応力へ の応答の仕方, 複合化の手段などの知識は個別蓄積 されてきている.これらの知識を集約して分子設計し てみることは, 生体汇学ぶ分子工学 (Biomimetic Molecular Engineering) の一分野を形成するだけ十 分な内容があると信ずる。私もすで若干試みつつは あるけれども，その成果を開陳する段階にないことを 残念飞思う. しかし, この方向こと与兄られた主題に 沿うものと信じて筆を拉く。

\section{文献}

1) 高楖素夫: 高分子, 20,342 (1971)

2) 高柳素夫: 同上, 22, 550 (1973)

3) S. N. Zhurkov, E.E. Tomashevsky: Proceedings of the Conference on the Physical Basis of Yield and Fracture, Oxford (1966) p 200; 文献 4) 参照.

4) H. H. Kausch: Polymer Sci. Symp., No. 32, 1 (1971)

5) K.E. Perepelkin: Mekhanika Polimerov, 2, 845 (1966)

6) D.K. Roylance, K.L. DeVries: Polymer Lett., B, 9, 443 (1971)

7) T. Nagamura, M. Takayanagi: J.Polymer Sci., A-2, 12, 2019 (1974)

8) T. Nagamura, K. Fukitani, M. Takayanagi: ibid., $A-2,13,1515$ (1975)

9）高柳素夫：工化，63，1492（1960）；旭硝子技術 奖励会報告, 7, 127 (1961)；8，97(1962)；日 
特公 昭 37-15484

10）木方 洋, 浅井健次郎：高分子討諭会予稿集 (1974) p 835

11) J. M. Andrews, I. M. Ward: J. Mater. Sci., 5, 411 (1970); G. Capaccio, I. M. Ward: Polymer, 15, 233 (1974)

12) N.E. Weeks, R. S. Porter: J. Polymer Sci.Phys., 12, 635 (1974)

13) D. M. Bigg: Polymer Eng. Sci., 16,725 (1976)

14) R.P. Kambour: J. Polymer Sci., A-2, 3,
1713 (1965); 4, 349 (1966); Appl. Polymer Symp., 7, 215 (1968)

15) R.S. Rivlin, A. G. Thomas: J. Polymer Sci., 10, 291 (1953)

16) E. H. Andrews: J. Mater. Sci., 9, 887 (1974)

17）深堀美英：日本ゴム協会誌，50，398（1977）

18) M. H. Miller, H. A. Sheraga: J. Polymer Sci, Polymer Symp., 54, 171 (1976)

19）奥山健二, 郷 信弘, 高柳素夫：日本生物物理学 会年会予稿集 (1977) p 138

\section{昭和 52 年科学技術調查}

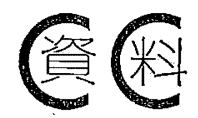

総理府統計局はこのほど, 51 年 度の科学技術研究調査の結果学 表した，不況にもかかわらず，実 質研究費の総額の伸びは石油ショ ック直前を上回って赦り，自然科 学部門では西ドイッを抜きアメリ カに次いで自由地界第二位の地位 を占めたのが大きな特色。

同調查は4月1日現在で (1) 全 国の資本金 300 万円以上の会社や 公社, 公団, 事業団, (2) 試験, 調查研究を業務とする国，公，民 営の機関, (3) 大学を対象に研究 費や研究人員について調べたも の. 約 1,100 の研究機関, 約 1,800 の大学についてはず゙て, 会社に ついては資本金により分類して約 12,200社を抽出した. 回収率は研 究機関, 大学とも $100 \%$, 会社な どは 85\%だった。

概要は次の通り。

自然科学部門の研究費は，2兆 9,414 億円に上る. この額はアメ リカの 11 兆 819 億円には及ばね いものの, 西ドイツの 2 兆 8,500 億円 (いずれも 1976 年の推定)を 抜く世界第 2 位の額で，国民所得 (145 兆円) の $2.03 \%$ に相当する.

研究費の負担割合は民間が 2 兆 3,415 億円, 国と地方公共団体が 9,765 億円で, 7 対 3 の比になっ て拈り，ここ 5 年間任ば変わって いない.

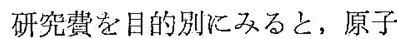
力開発が 1,300 億円で前年度に比 ベて $36.1 \%$ も伸びた. 次が海洋 開発の 183 億円で前年度より 16.6 \%増，50 年度に $50 \%$ の俋びを示 した宇宙開発は，事業が一段落し たため $9 \%$ の伸びにとどまり， 794億円. 情報処理は民間を主体に

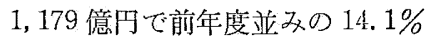
の伸び．かって花形だった公害防 止などの環境保護関係は 1,078 億 円で前年度より $0.4 \%$ 減った。 会社などの研究費は電気機械, 化学, 輸送用機械の三業界で全体 の $60 \%$ を占め, 対前年度比では 金属製品工業 (37.5\% 増), 䆛業 (24.9\% 増), 電気機械 $(22.8 \%$ 増）などが高い，とくに電気機栰 業界は壳り上け゚に対する研究費比 率でも $3.7 \%$ と群を抜いて高く, 次いで化学 $(2.4 \%)$, 精密機械 (同) が高い。たた研究費の集中

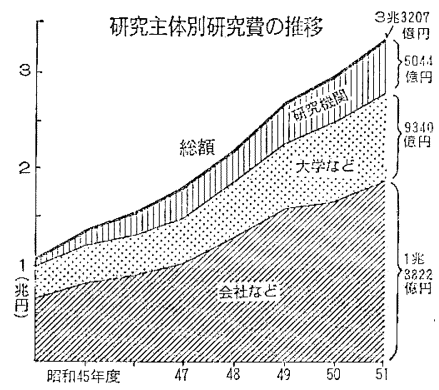

度をみると，研究費の“寡占”が 進えでいるのは鉄鋼業（上位 5 社 で $80.3 \%$ を占める), 出版・印刷 業 (同 $74.1 \%$ )，ゴム製品工萆 (同 $67.7 \%)$. 逆洤金属製品工業 (17.5 $\%)$, 化学 (81.0\%) は集中化され ていない代表例.

研究者数恃全体で 59 万 5,000 人, らち研究を主務とするのは 32 万 9,000 人で, 50 年度より 1 万 3,000 人増克て扣り，国民 1 万人 の5ち 29 人が研究者. 破究者の らち会社などに属するもの 31 万 人, 大学 21 万 2,000 人, 研究機 関 7 万 3,000 人. 女子の研究主務
者休 1 万 9,000 人で全体の $6 \%$ ， 大半 ( 1 万 6,000 人) 分大学にい 万.

\section{石油の海洋備蓄にプラスチック}

石油の備蓄がェネルギ一政策の 重要な柱になっているが, 工業技 術院の製品研科学究所 (東京都大 田区下丸子） は，53 年度から5 年 計画で総力を結集して, 石油の海 洋貯蔵の研究に取り組さ.プラス チックの袋の中に石油を人れ，波 静かな海面に浮かべた状態で貯蔵 しようというもので, 備蓄の採算 点といわ狆る $1 \mathrm{k} l$ 当たり 2 万 5,000円〜3 万円の コスト内に十 分和さ学名という。

これまでの検討結果では，プラ スチック材料としては，ポリエス テル,ビニロン繊維を補強材にし た厚さ数 $\mathrm{mm}$ のポリエチレン, 塩化ビニル, 塩化ビニリデンのシ 一トを使ら、これで大きな球形， ドーナッ形, 招そな党形, 円筒形 の容器をつくり，タンカーなどか ら石油を入れる。これを波の静か な入り汇に浮かべて拉くわけだ。 容器はシート一枚仕上げとせず に,アドバルーンのように舟形の 何枚かのシートを接着剤や熱溶接 (ヒート・シール) で張り合わせ球 形組み立てる. 直径 $40 \mathrm{~m}$ の球 形容器でも, 入る量は. 3 万 3,000 $\mathrm{k} l$. 大量䚚蓄にはいくつも浮かべ な社格ならない（読売 1.5） 